
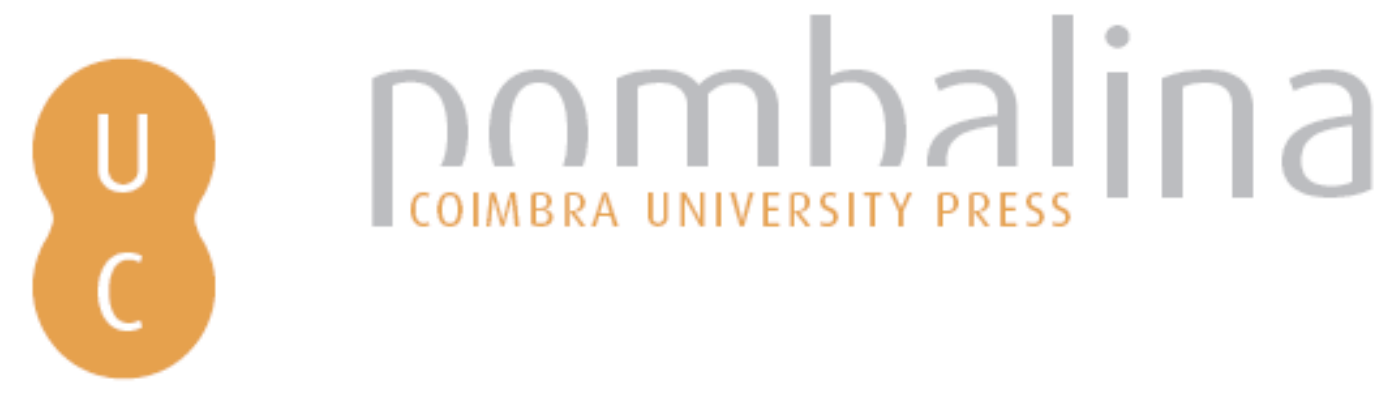

\title{
The ring of fire: the relative importance of fuel packing versus intrinsic leaf flammability
}

\author{
Autor(es): $\quad$ Grootemaat, Saskia; Wright, lan J.; Cornelissen, Johannes H. C. \\ Publicado por: Imprensa da Universidade de Coimbra \\ URL \\ persistente: URI:http://hdl.handle.net/10316.2/34138 \\ DOI: $\quad$ DOI:http://dx.doi.org/10.14195/978-989-26-0884-6_51 \\ Accessed : $\quad$ 26-Apr-2023 09:45:57
}

A navegação consulta e descarregamento dos títulos inseridos nas Bibliotecas Digitais UC Digitalis, UC Pombalina e UC Impactum, pressupõem a aceitação plena e sem reservas dos Termos e Condições de Uso destas Bibliotecas Digitais, disponíveis em https://digitalis.uc.pt/pt-pt/termos.

Conforme exposto nos referidos Termos e Condições de Uso, o descarregamento de títulos de acesso restrito requer uma licença válida de autorização devendo o utilizador aceder ao(s) documento(s) a partir de um endereço de IP da instituição detentora da supramencionada licença.

Ao utilizador é apenas permitido o descarregamento para uso pessoal, pelo que o emprego do(s) título(s) descarregado(s) para outro fim, designadamente comercial, carece de autorização do respetivo autor ou editor da obra.

Na medida em que todas as obras da UC Digitalis se encontram protegidas pelo Código do Direito de Autor e Direitos Conexos e demais legislação aplicável, toda a cópia, parcial ou total, deste documento, nos casos em que é legalmente admitida, deverá conter ou fazer-se acompanhar por este aviso.

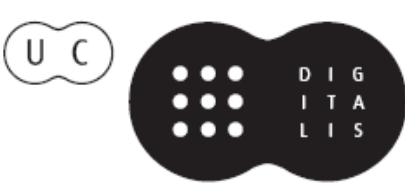




\section{ADVANCES IN}

Forest Fire

\section{RESEARCH}

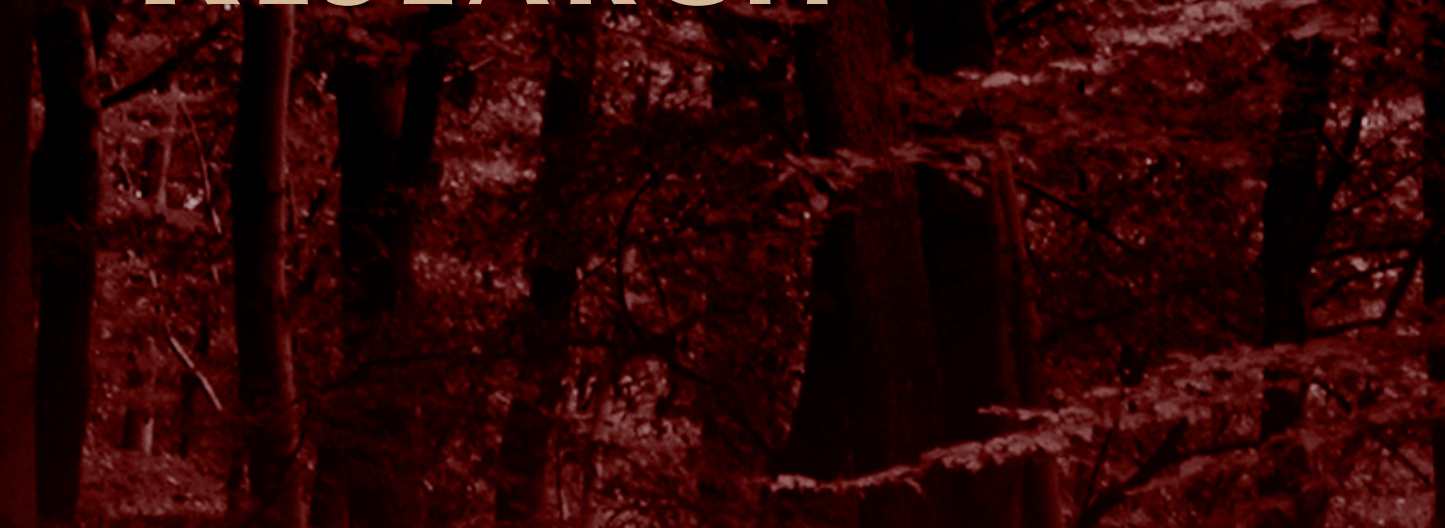

\section{DOMINGOS XAVIER VIEGAS}

\section{EDITOR}




\title{
The ring of fire: the relative importance of fuel packing versus intrinsic leaf flammability
}

\author{
Saskia Grootemaat ${ }^{\mathrm{a}}$, Ian J. Wright ${ }^{\mathrm{a}}$ and Johannes H. C. Cornelissen ${ }^{\mathrm{b}}$ \\ ${ }^{a}$ Department of Biological Sciences, Macquarie University, Sydney, NSW 2109, Australia; \\ saskia.grootemaat@mq.edu.au,ian.wright@mq.edu.au \\ ${ }^{b}$ System Ecology, Faculty of Earth and Life Sciences, VU University, 1081 HV Amsterdam, \\ The Netherlands; j.h.c.cornelissen@vu.nl
}

\begin{abstract}
Two different experimental set-ups were used to disentangle the relative importance of intrinsic leaf traits versus fuel packing for the flammability in fuel beds. Dried leaves from 25 Australian perennial species were burnt in fuel bed rings under controlled conditions. The flammability parameters were compared with the results of a previous study where individual leaves from the same species were burnt in a muffle furnace at $400^{\circ} \mathrm{C}$. Fuel density (g fuel per volume) was the dominant driver for the combustibility and sustainability of the fire in the fuel bed rings; e.g., loosely packed fuel beds showed higher rates of spread. Specific leaf area (SLA, ratio of leaf area to dry mass) was not only the strongest predictor of "time-to-ignition" in the furnace set-up (higherSLA species having shorter ignition times), but also played a major role in the build-up of the fuel bed, and thus the flammability in fuel beds.
\end{abstract}

Keywords: combustibility, fire behaviour, fuel bed density, leaf traits, specific leaf area

\section{Introduction}

During high intensity wildfires any organic matter will likely burn. However, at lower intensities the intrinsic properties of fuel, like fuel moisture content or leaf dimensions, can strongly influence fire behaviour (Scarff and Westoby 2006; Plucinski and Anderson 2008). In a previous study we showed that intrinsic chemical and morphological properties of leaves had strong and differential effects on the ignitibility and sustainability of fire (Grootemaat et al., in review). Species with higher specific leaf area (SLA) and lower moisture content showed shorter ignition times. Leaf nitrogen (N), phosphorus $(\mathrm{P})$ and tannin concentrations favoured the combustion process towards charring rather than tarring, thereby shortening the flame duration and prolonging the smouldering phase (Grootemaat et al., in review).

In fuel beds however, fuel bed density ( $\mathrm{g}$ fuel per volume) and packing ratio $\left(\mathrm{cm}^{3}\right.$ fuel per volume) are strong drivers of fire spread (Scarff and Westoby 2006; Engber and Varner 2012; de Magalhães and Schwilk 2012; Van Altena et al. 2012). Based on principles of air-flow, more densely packed fuel beds are restricted in their oxygen supply and will therefore face difficulties with their combustion (Byram 1959; Drysdale 2011).

In this study we quantified the relative importance of leaf traits and packing on the sustainability, combustibility and consumability of fire burning through fuel beds. We examined if the same drivers were important for the "flammability" of a) individual leaves and b) fuel beds. Does the ranking in species' flammability differ between the two types of experimental set-ups? We expected that the physical configuration of the leaves would dominate over the "intrinsic' effects of leaf chemistry and morphology. We also expected that leaf size and "curliness" would be the main drivers of fuel bed density, with larger and curlier leaves forming more aerated fuel beds and therefore leading to a higher combustibility (i.e. higher rate of spread, or shorter flame residence time). 


\section{Methods}

Experimental burns were performed on monospecific fuel beds consisting of dried green leaves from 25 perennial Australian species, a subset of those used in the previous experiments (Table S1). These species were sampled from four vegetation types in New South Wales, eastern Australia (details in Wright et al. 2001). The burning experiments were run at the FLARE Lab (Fire Laboratory of Amsterdam for Research in Ecology; VU University, The Netherlands). Fuel beds were burnt following standard procedures (Van Altena et al. 2012). In short, air-dried leaves were placed loosely in a steel mesh ring ( $25 \mathrm{~cm}$ in diameter, $3 \mathrm{~cm}$ high). The leaves were equally distributed over the ring until the ring was full, resulting in an equal volume of fuel for all replicates. Six thermocouples were positioned approximately $1 \mathrm{~cm}$ above the fuel bed. Samples were ignited by lighting a cotton disk injected with $1 \mathrm{ml}$ of ethanol (96\%), which was placed in the middle of the ring. Different flammability parameters were measured (Table 1) and compared to the results from our previous study. Furthermore, the role of leaf traits (Table S2) for species' flammability was analysed.

Table 1. Overview of the measured flammability variables during the experimental burns (species' means). The first six variables were measured in the fuel bed rings; the last four (shaded) variables came from our previous work on flammability of individual leaves in a muffle furnace at $400^{\circ} \mathrm{C}$

\begin{tabular}{|c|c|c|c|c|}
\hline Variable & Description & $\begin{array}{l}\text { Flammability } \\
\text { component }\end{array}$ & Unit & Range \\
\hline Ignition frequency & $\begin{array}{l}\text { Percentage of replicates that truly } \\
\text { ignited (with flames rather than } \\
\text { smouldering) }\end{array}$ & Ignitibility & $\%$ & $33.3-100$ \\
\hline Maximum temperature & $\begin{array}{c}\text { Mean maximum temperature for } 5 \\
\text { sensors }\end{array}$ & Combustibility & ${ }^{\circ} \mathrm{C}$ & $480-753$ \\
\hline Total heat released & $\begin{array}{c}\text { Area under the temperature*time } \\
\text { curve }\end{array}$ & Combustibility & ${ }^{\circ} \mathrm{C} * \min$ & $200-2620$ \\
\hline Rate of spread & $\begin{array}{l}\text { Distance from the ignition point to } \\
\text { the edge of the ring, divided by time } \\
\text { to edge }\end{array}$ & Combustibility & $\mathrm{cm} / \mathrm{s}$ & $0.05-0.64$ \\
\hline Burning time & $\begin{array}{l}\text { Fire duration; time from ignition at a } \\
\text { sensor until the fire dies out at that } \\
\text { sensor (mean of } 5 \text { sensors, threshold } \\
\text { used is } 50^{\circ} \mathrm{C} \text { ) }\end{array}$ & Sustainability & $\mathrm{s}$ & $61-1407$ \\
\hline Fuel consumption & Percentage weight lost & Consumability & $\%$ & $67-98$ \\
\hline Time to ignition & $\begin{array}{l}\text { Time from the insertion of a leaf into } \\
\text { a muffle furnace }\left(400^{\circ} \mathrm{C}\right) \text { until the } \\
\text { first visible flame }\end{array}$ & Ignitibility & $\mathrm{s}$ & $1.1-7.0$ \\
\hline Flame duration & $\begin{array}{l}\text { Time from the first visible flame } \\
\text { until no more flames could be seen }\end{array}$ & Sustainability & $\mathrm{s}$ & $0.8-10.6$ \\
\hline Smouldering duration & $\begin{array}{l}\text { Time from the end of the last visible } \\
\text { flame until the glowing phase died } \\
\text { out }\end{array}$ & Sustainability & $\mathrm{s}$ & $2.4-46.0$ \\
\hline Total burning time & $\begin{array}{c}\text { Sum of flame- and smouldering } \\
\text { duration for individual leaves in a } \\
\text { muffle furnace }\end{array}$ & Sustainability & $\mathrm{s}$ & $3.2-56.7$ \\
\hline
\end{tabular}




\section{Preliminary results}

\subsection{Which leaf traits are important for the flammability in fuel beds?}

Fuel bed density $\left(\mathrm{g} / \mathrm{cm}^{3}\right)$ was by far the most important driver for rate of spread $\left(\mathrm{R}^{2}=0.81, \mathrm{p}<0.001\right.$; Figure 1a). Fuel beds which were more densely packed (more mass per ring-volume), showed a slower spread of the fire. This can be understood as a simple "mass-effect", i.e. higher fuel loads require more time for combustion. On the other hand, the combustion process itself could have been limited by oxygen supply. When fuel beds were more densely packed there was less physical space for airflow, leading to partly incomplete combustion. Indeed we found that the mass of unburnt material was higher when the fuel bed density was higher $\left(\mathrm{R}^{2}=0.29, \mathrm{p}=0.006\right)$. Interspecific variation in fuel bed density itself was mostly driven by specific leaf area $\left(R^{2}=0.72, p<0.001\right)$ and leaf curliness $\left(R^{2}=0.61, p\right.$ $<0.001$ ), and only to a lesser extent by leaf size (expressed as one side surface area, $\mathrm{R}^{2}=0.19, \mathrm{p}=$ 0.036 ).

Specific leaf area (SLA) and leaf curliness also showed direct effects on the rate of spread (Figure $1 \mathrm{~b}$ and c). Species with curlier leaves, and species with higher SLA, showed a higher rate of fire spread through the fuel bed. Most likely this is a side effect of the packing: curled leaves or species with higher SLA decreased the density of the fuel beds and therefore increased the rate of fire spread.

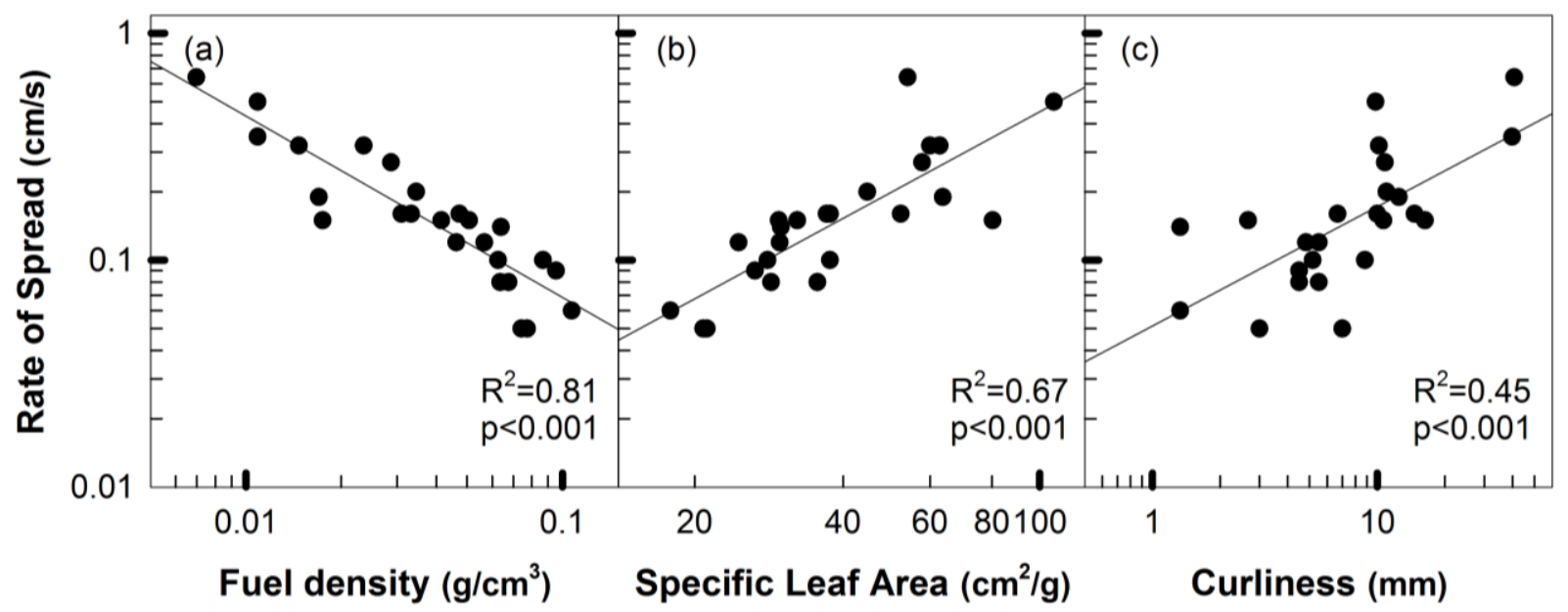

Figure 1. Bivariate relationships between "Rate of Spread" and (a) fuel bed density, (b) Specific Leaf Area and (c) leaf curliness. Each dot represents a species-mean. $R^{2}$ - and p-values for the regression lines are given in the figure.

\subsection{Does the ranking in species' flammability hold in two different experimental set-ups?}

In contrast to our expectations we did not find a relationship between the fire-duration (total burning time) in individual leaves and the burning time in fuel beds. However, individual-leaf "time-toignition" showed clear relationships with four of the fuel bed fire parameters (Table 2). Most notably, the shorter the time-to-ignition of individually burnt leaves, the higher the rate of spread through the same species arranged in fuel beds $\left(\mathrm{R}^{2}=0.59, \mathrm{p}<0.001\right)$. Rate of spread can thus be seen as an accumulation of "ignition-steps".

In our previous study on individual leaves, interspecific variation in ignition times was strongly driven by specific leaf area $\left(\mathrm{R}^{2}=0.70, \mathrm{p}<0.001\right)$. Our results here suggest that SLA is the main driver of fuel density and consequently has a major influence of the combustibility in fuel beds. Leaf size and surface area per volume $(\mathrm{SA}: \mathrm{V})$ appeared to be less important than SLA. 
Table 2. Intrinsic leaf flammability versus flammability in fuel beds. Only leaf intrinsic "time-to-ignition" showed significant relationships with (four out of five) fuel bed flammability parameters. The direction of the relation is expressed by "+" for positive relationships, and "-" for negative relationships; $n s=$ not significant.

\begin{tabular}{|cccccc|}
\hline & $\begin{array}{c}\text { Maximum } \\
\text { Temperature } \\
\left({ }^{\circ} \mathbf{C}\right)\end{array}$ & $\begin{array}{c}\text { Total Heat } \\
\text { Released } \\
\left({ }^{\circ} \mathbf{C}^{*} \mathbf{m i n}\right)\end{array}$ & $\begin{array}{c}\text { Rate of } \\
\text { Spread } \\
(\mathbf{c m} / \mathbf{s})\end{array}$ & $\begin{array}{c}\text { Burning } \\
\text { time } \\
(\mathbf{s})\end{array}$ & $\begin{array}{c}\text { Fuel } \\
\text { consumption } \\
(\%)\end{array}$ \\
\hline Time To Ignition (s) & $\mathrm{R}^{2}=0.37(+)$ & $\mathrm{R}^{2}=0.67(+)$ & $\mathrm{R}^{2}=0.59(-)$ & $\mathrm{R}^{2}=0.66(+)$ & $\mathrm{ns}$ \\
& $\mathrm{p}=0.002$ & $\mathrm{p}<0.001$ & $\mathrm{p}<0.001$ & $\mathrm{p}<0.001$ & \\
Flame Duration (s) & $\mathrm{ns}$ & $\mathrm{ns}$ & $\mathrm{ns}$ & $\mathrm{ns}$ & $\mathrm{ns}$ \\
Smoulder Duration $(\mathbf{s})$ & $\mathrm{ns}$ & $\mathrm{ns}$ & $\mathrm{ns}$ & $\mathrm{ns}$ & $\mathrm{ns}$ \\
Total Burning Time (s) & $\mathrm{ns}$ & $\mathrm{ns}$ & $\mathrm{ns}$ & $\mathrm{ns}$ & $\mathrm{ns}$ \\
\hline
\end{tabular}

\section{Acknowledgements}

Thanks to Richard van Logtestijn for his help with the experimental set up. Veronica Shaw and Vincent Maire helped with the collection of leaf material in Round Hill nature reserve. This project was funded by a scholarship from Macquarie University to S.G. and additional funding by VU University.

\section{References}

Byram GM (1959) Combustion of forest fuels. 'Forest Fire: Control and Use' (ed. K.P. Davis), pp. 155-182. McGraw-Hill, New York.

de Magalhães RMQ, Schwilk DW (2012) Leaf traits and litter flammability: evidence for non-additive mixture effects in a temperate forest. Journal of Ecology 100(5), 1153-1163.

Drysdale D (2011) 'An Introduction to Fire Dynamics.' ${ }^{\text {rd }}$ edn. (John Wiley \& Sons), West Sussex, UK.

Engber EA, Varner JM III (2012) Patterns of flammability of the California oaks: the role of leaf traits. Canadian Journal of Forest Research 42, 1965-1975.

Plucinski MP, Anderson WR (2008) Laboratory determination of factors influencing successful point ignition in the litter layer of shrubland vegetation. International Journal of Wildland Fire 17(5), 628-637.

Scarff FR, Westoby M (2006) Leaf litter flammability in some semi-arid Australian woodlands. Functional Ecology 20(5), 745-752.

Van Altena C, van Logtestijn R, Cornwell W, Cornelissen H (2012) Species composition and fire: non-additive mixture effects on ground fuel flammability. Frontiers in Plant Science 3, 1-10.

Wright IJ, Reich PB, Westoby M (2001) Strategy shifts in leaf physiology, structure and nutrient content between species of high- and low-rainfall and high- and low-nutrient habitats. Functional Ecology 15(4), 423-434.

\section{Supplementary Information}

Table S1- Species list

\begin{tabular}{|lllllc|}
\hline Genus & Species & Family & Rainfall $^{a}$ & Soil P $^{b}$ & No. of replicates \\
\hline Acacia & doratoxylon & Fabaceae & low & high & 5 \\
Acacia & havilandiorum & Fabaceae & low & low & 1 \\
Allocasuarina & sp. & Casuarinaceae & high & high & 5 \\
Astrotricha & floccosa & Araliaceae & high & high & 5 \\
Brachychiton & populneus & Malvaceae & low & low & 6 \\
\hline
\end{tabular}




\begin{tabular}{|llllll|}
\hline Corymbia & gummifera & Myrtaceae & high & low & 6 \\
Dodonaea & viscosa spathulata & Sapindaceae & low & high & 1 \\
Eremophila & longifolia & Myoporaceae & low & high & 5 \\
Eucalyptus & dumosa & Myrtaceae & low & low & 3 \\
Eucalyptus & haemastoma & Myrtaceae & high & low & 6 \\
Eucalyptus & intertexta & Myrtaceae & low & high & 6 \\
Eucalyptus & socialis & Myrtaceae & low & low & 4 \\
Geijera & parviflora & Rutaceae & low & high & 6 \\
Hakea & dactyloides & Proteaceae & high & low & 4 \\
Hakea & tephrosperma & Proteaceae & low & high & 2 \\
Hakea & teretifolia & Proteaceae & high & low & 1 \\
Lambertia & formosa & Proteaceae & high & low & 1 \\
Lasiopetalum & ferrugineum & Malvaceae & high & high & 6 \\
Lomatia & silaifolia & Proteaceae & high & high & 6 \\
Macrozamia & communis & Zamiaceae & high & high & 5 \\
Persoonia & levis & Proteaceae & high & low & 3 \\
Santalum & acuminatum & Santalaceae & low & low & 3 \\
Syncarpia & glomulifera & Myrtaceae & high & high & 4 \\
Synoum & glandulosum & Meliaceae & high & high & 6 \\
Triodia & scariosa & Poaceae & low & low & 5 \\
\hline
\end{tabular}

${ }^{a}$ Low rainfall sites receive approximately $383 \mathrm{~mm}$ rainfall per year, high rainfall sites $1233 \mathrm{~mm}$.

${ }^{b}$ Low soil phosphorus levels are below $132 \mu \mathrm{g} / \mathrm{g}$; high soil phosphorus levels are above $250 \mu \mathrm{g} / \mathrm{g}$ (Wright et al. 2001).

Table S2 - Trait overview

\begin{tabular}{|c|c|c|c|}
\hline Traits & Description & Units & Range \\
\hline Fuel bed density & Mass of sample per fuel bed volume & $\mathrm{g} / \mathrm{cm}^{3}$ & $0.00697-0.10707$ \\
\hline Fuel bed packing ratio & Particle volume per fuel bed volume & $\begin{array}{l}\text { dimensionless } \\
\left(\mathrm{cm}^{3} / \mathrm{cm}^{3}\right)\end{array}$ & $0.000024-0.001129$ \\
\hline Leaf curliness & $\begin{array}{l}\text { Height above the flat leaf surface, } \\
\text { including petiole (perpendicular to } \\
\text { leaf length) }\end{array}$ & $\mathrm{mm}$ & $1.33-40.67$ \\
\hline Leaf size & One sided surface area & $\mathrm{cm}^{2}$ & $0.82-32.61$ \\
\hline Leaf dry mass & Oven dry weight & g & $0.01-1.03$ \\
\hline Leaf SA/V & $\begin{array}{l}\text { One sided leaf surface area per } \\
\text { volume }\end{array}$ & $\mathrm{cm}^{-1}$ & $11.42-31.06$ \\
\hline SLA & One sided leaf area per dry mass & $\mathrm{cm}^{2} / \mathrm{g}$ & $17.86-106.89$ \\
\hline Leaf N & Nitrogen concentration & $\%$ mass & $0.61-2.19$ \\
\hline Leaf $P$ & Phosphorus concentration & $\%$ mass & $0.02-0.11$ \\
\hline Leaf lignin & $\begin{array}{l}\text { Difference between the sum of non- } \\
\text { polar, water soluble, and acid soluble } \\
\text { fractions from the total sample }\end{array}$ & $\%$ mass & $8.72-37.50$ \\
\hline Leaf tannin & Soluble polyphenols & $\%$ mass & $1.79-18.50$ \\
\hline Leaf thickness & & $\mathrm{mm}$ & $0.33-1.28$ \\
\hline Leaf length & & $\mathrm{mm}$ & $43-128$ \\
\hline Leaf width & & $\mathrm{mm}$ & $3-43$ \\
\hline
\end{tabular}

